\title{
INDIVIDUAL AND MATERNAL ASPECTS OF ATHLETE CRIOULO HORSES
}

\author{
SANTOS, Fernanda Carlini Cunha dos ${ }^{1}$; \\ CURCIO, Bruna da Rosa ${ }^{2}$; \\ NOGUEIRA, Carlos Eduardo Wayne ${ }^{2}$.
}

Received: $22 / 03 / 2018$

Accepted: $14 / 08 / 2018$

${ }^{1}$ Departamento de Medicina Veterinária, Curso de Medicina Veterinária, Universidade Federal de Roraima (UFRR), Boa Vista, Roraima (RR), Brasil; ${ }^{2}$ Departamento de Clínicas Veterinárias, Faculdade de Veterinária (FVet), Universidade Federal de Pelotas (UFPEL), Capão do Leão, Rio Grande do Sul (RS), Brasil.

\section{ABSTRACT}

- reio de Ouro is a competition exclusively for Crioulo horses, officially promoted for over 30 years. Performance of equine athletes are correlated to maternal characteristics. This study aimed to describe individual and maternal aspects of athlete Crioulo horses that have won the Freio de Ouro competition. A retrospective study was performed with the data collected in the genealogical service of ABCCC, between the years 1982 and 2012. Data analyzed were the animals' age at winning, maternal age at first parturition, maternal age at the winner's parturition, and parturition order. Descriptive statistics were performed with a computer program. Mean age of winners was $7.1 \pm 0.17$ years, $95.4 \%$ of the animals won between 4 and 11 years old and 3.2\% after 12 years old. Mean maternal age at first parturition was $6 \pm 0.19,53.6 \%$ of the females delivered before 5 years and, consequently, $46.4 \%$ at 6 years or over. Mean maternal age at parturition of the winners was $9.2 \pm 0.37$ years. In the range between 5 and 8 years, $50.3 \%$ of the champions were born. Approximately $5.9 \%$ of mares delivered champions when 4 years or younger, whereas $15.6 \%$ delivered at over 15 years. Around $28 \%$ of the champions were born from primiparous mares, $53.7 \%$ from $2^{\text {nd }}-5^{\text {th }}$ birth, and $18.3 \%$ were from their dams $6^{\text {th }}-12^{\text {th }}$ delivery. The present study provides retrospective information regarding individual and maternal aspects of athlete Crioulo horses that have won the Freio de Ouro over the last 30 years.

Keywords: Age. Birth. Champions. Parturition. Performance. 


\section{INTRODUCTION}

There are over 400,000 registered horses across the Brazilian territory and in South America (including Uruguay, Argentina, Chile and Paraguay), North America and Europe, according to the Brazilian Association of Crioulo Horse Breeders (Associação Brasileira de Criadores de Cavalos Crioulos) (ABCCC, 2017). Turnover for the Crioulo horse has risen quickly over the years, and by the end of 2016 this amount was nearly $\mathrm{R} \$ 1.28$ billion (reais) considering all commercialization during one year (ABCCC, 2017). The most important competition exclusively for athlete Crioulo horses is the Freio de Ouro. The Freio de Ouro competition is composed of morphology evaluation, through the animal framework within the breed standards, and functionality, through performance. There are no reports about individual and maternal characteristics of athlete Crioulo horses that won the Freio de Ouro competition.

Maternal characteristics, including age at birth and number of previous pregnancies, have been evaluated and correlated to the growth and performance of equine athletes (HARRIS, 2008). In Thoroughbred horses, maternal age, parity order, and performance of their foals in races are highly correlated (FINOCCHIO; ROSENZWEIG, 1995). Previous studies on Thoroughbred winner foals have shown that only a low percentage of winners were born from old mares, above 12 years of age (GARCIA et al., 2011). An increase in female age is associated with reduced reproductive competence (MORRIS; ALLEN, 2002). Reproductive senescence is characterized by a decline in fertility, since in stallions the sperm quality and libido fall, whereas in mares a progressive degeneration of the endometrium occurs, with a consequent loss in adequate uterine nutrition for the embryo/fetus (WILSON, 2007) due to placental-maternal-fetal relation area of contact (WILSHER; ALLEN, 2003). Both maternal age and parity order may affect the performance of progeny in Thoroughbred horses (O'SULLIVAN, 1980).

The aim of this study was to describe individual (animal's age at time of winning the competition) and maternal aspects (maternal age at birth, age at first birth, and parity order) of athlete Crioulo horses that have won the Freio de Ouro competition over the last 30 years. 


\section{MATERIAL AND METHODS}

A retrospective study was performed with the data collected in the genealogical service of the $A B C C C$, which has its headquarters located in the city of Pelotas, Rio Grande do Sul, Brazil, and an extensive database containing documents on registered horses, stallions, breeding, and reproductive history of mares. From this database, individual aspects (age of the horse at the time of winning the competition) and maternal characteristics (maternal age at first parturition, maternal age at parturition of the winner, and parity order) were analyzed.

The data analyzed were from all the champions of the Freio de Ouro competition, including those in first (gold - Freio de Ouro), second (silver - Freio de Prata), and third (bronze - Freio de Bronze), place, in the period between the years 1982 and 2012. From 1982 to 2012, 153 horses were recorded as Freio de Ouro winners. Between the years 1982 and 1992, males and females competed in the same category, regardless of gender. Since 1993 the competitors have been divided according to gender. Collected information was tabulated for later evaluation. Descriptive statistics were performed with all data with the computer program Statistix $9^{\circledR}$ (Statistix, Statistix 9 for Windows, Analytical Software, Tallahassee, FL, USA, 2008).

\section{RESULTS AND DISCUSSION}

General mean was performed considering all winners of the Freio de Ouro competition between 1992 and 2012 (Figure 1-4).

The mean age of winners was $7.1 \pm 0.17$ years old. According to frequency distribution (Figure 1), $95.4 \%(147 / 154)$ of horses have won the competition at 4-11 years old. This may be because mature animals, which have already stopped growing, can withstand intense training and present good performance in this high-level competition. In the Crioulo breed, foals' distal radius physis radiologically ceases its activity by 25 months of age (LUIZ et al., 2007). Similarly, in Thoroughbreds physis ceases between 23 and 25 months of age; in the Mangalarga and Brasileiro de Hipismo horse breeds physis ceases around 25 months (VULCANO et al., 1997). Only 1.3\% (2/154) have won the competition at 3 years old and $3.2 \%$ 
(5/154) aged 12 years or older. Intensive training and competing favor lesions, mainly in the musculoskeletal system, thereby decreasing the longevity of the equine sports career.

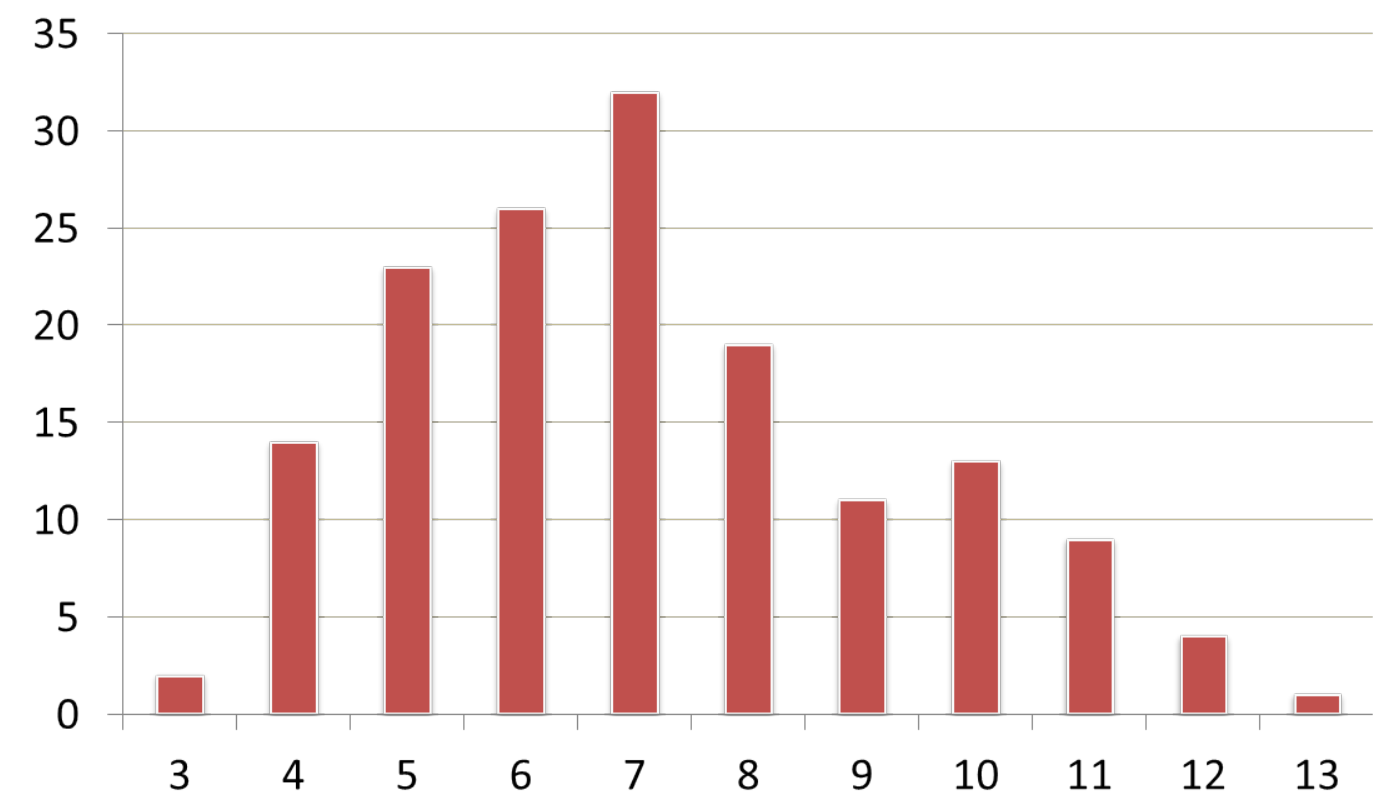

Figure 1 - Frequency distribution of the age of Freio de Ouro winners in the years 1982-2012.

The mean age at first birth was $6 \pm 0.19$ years; $53.6 \%$ (74/138) of females had delivered before 5 years of age and, consequently, 46.4\% (64/138) after 6 years (Figure 2). The equine female reaches sexual maturity, i.e., the simple capacity of generating successors, around 10-24 months of age (DAVIES-MOREL, 2003). At 3 years old, $8 \%(11 / 138)$ of the mares had undergone one delivery, indicating that these mares were covered just after being considered sexually mature. Considering the physiological gestational period (335 days), $68.8 \%(95 / 138)$ of females entered the breeding program at younger than 6 years of age. The ideal age for mares to start the breeding program is around 5-6 years, when the mares have reached their adult size and the growth phase has ended (DAVIES-MOREL, 2003). Only $5.8 \%(8 / 138)$ of females had their first birth at 10 years or older. The mares in this category are considered old and have less chance of conception and pregnancy maintenance, mainly due to degenerative endometrial changes. 


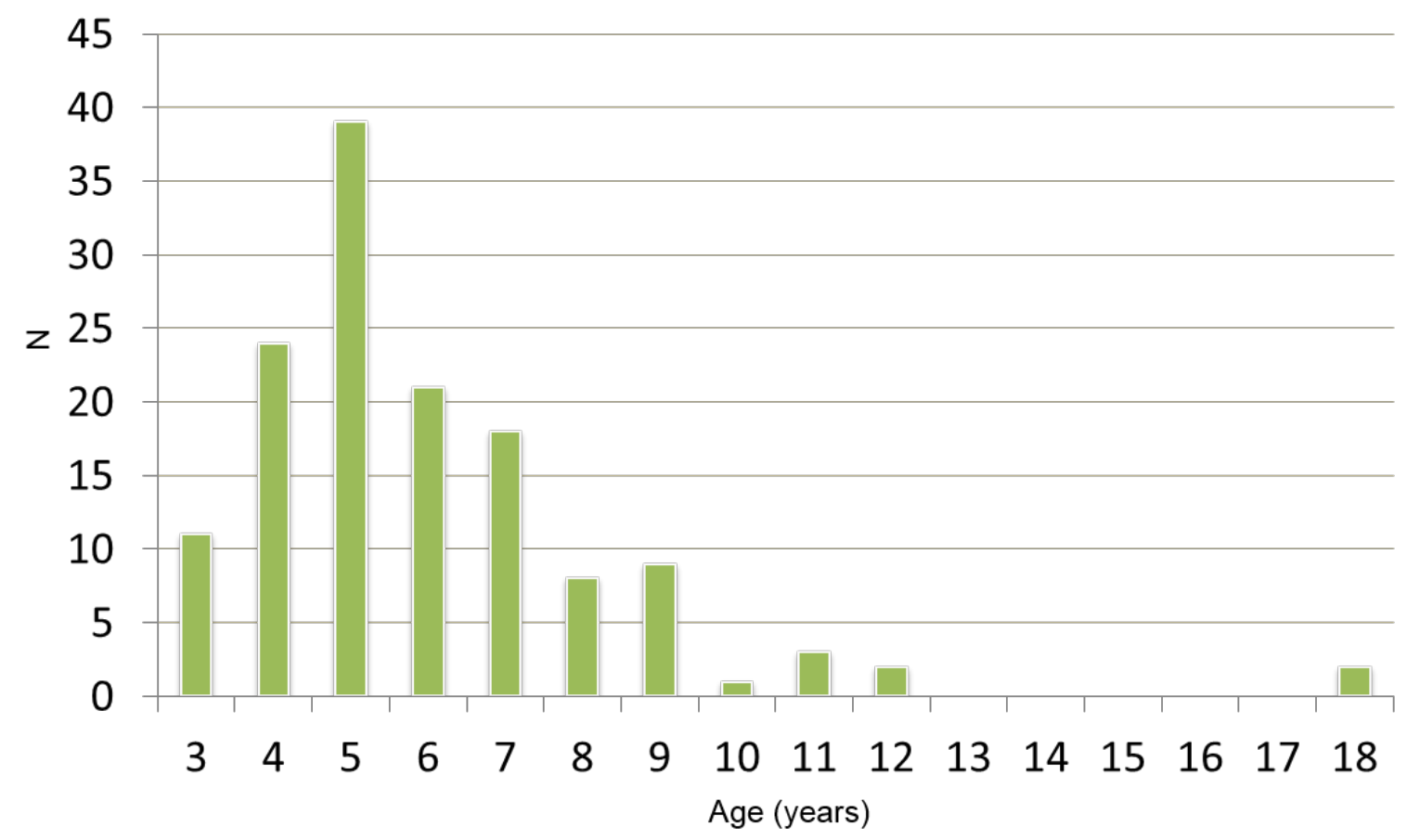

Figure 2 - Frequency distribution of maternal age at first birth in the years 1982-2012.

The mean maternal age at parturition of the winners was $9.2 \pm 0.37$ years. In the range between 5 and 8 years old, 50.3\% (77/153) of the champions were born. In this age group, the mare is considered mature. In Thoroughbred horses, a greater incidence is found of foals born from mares aged 6-10 years (FINOCCHIO; ROSENZWEIG, 1995). Additionally, a high frequency is found of foals that had won important races born from mares aged 5-12 years among Thoroughbreds in the South of Brazil (GARCIA et al., 2011). In this breed, the younger the foal/colt starts in a sports career the better. According to the rules of the Thoroughbred Stud Book, when a horse starts in a breeding program it cannot return to races, so it is expected that young mares first have their sports career and subsequently start in breeding programs. Due to this rule, most Thoroughbred mares start reproductive management at an older age. The $A B C C C$ does not have rules regarding breeding programs and the sports career. However, only 5.9\% (9/153) of Crioulo mares delivered champions when they were 4 years old or less (Figure 3). 


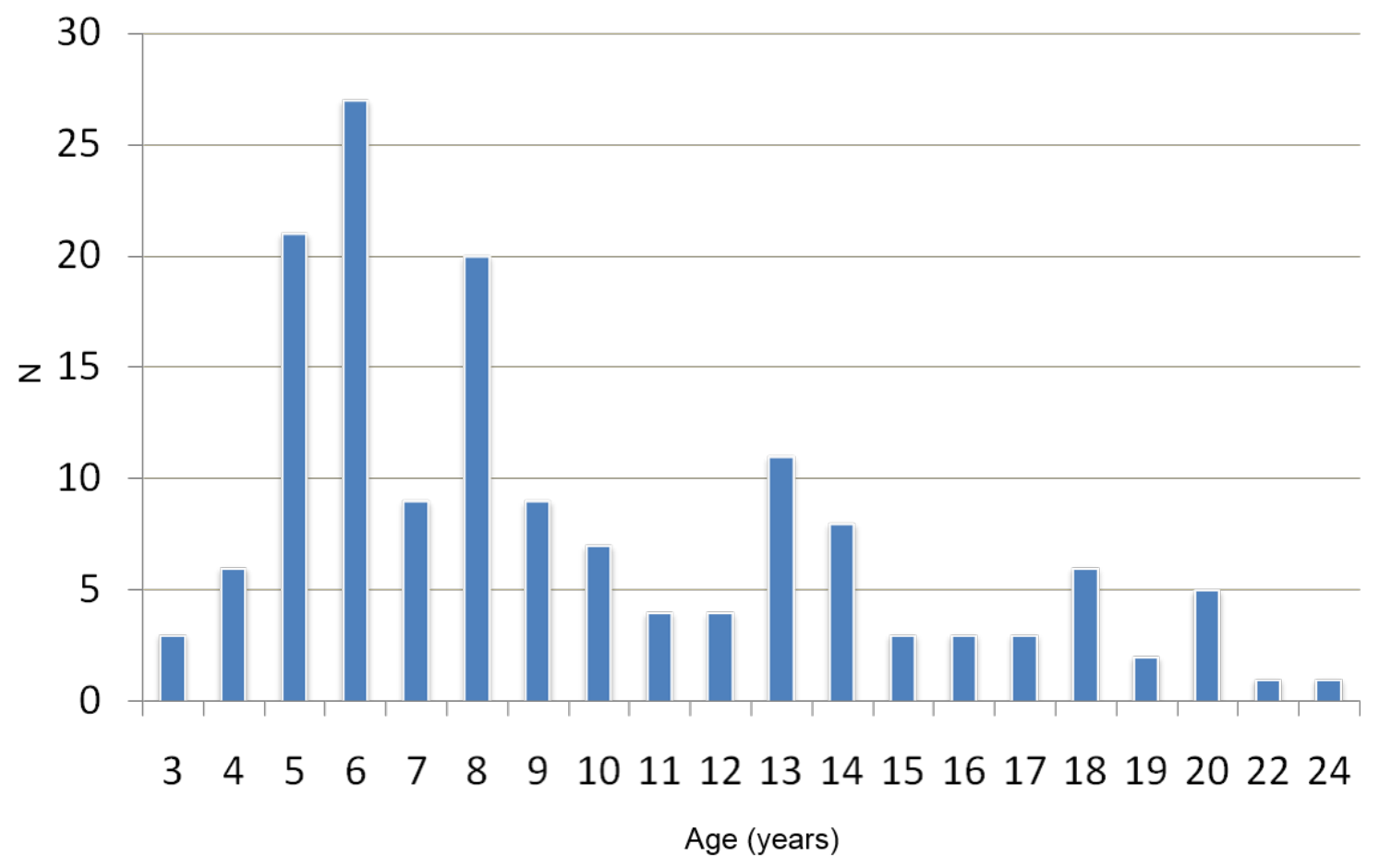

Figure 3 - Frequency distribution of maternal age at birth of winners of Freio de Ouro competition in the years 1982-2012.

In contrast, older mares (over 15 years of age) accounted for only $15.6 \%$ (24/153) of those that delivered the winning foal. Older mares tend to have disturbances in maternal-fetal circulation and uterine disorders, which may limit conceptus development and influence their future athletic performance (ROSSDALE, 2004). Low percentage of winners were delivered from mares above 12 years of age (GARCIA et al., 2011).

Age and number of births have an important role in relation to placental-maternal-fetal microscopic contact area and how efficient this contact is for nutrient transference to the conceptus (WILSHER; ALLEN, 2003). Maternal age and parity order may affect the performance of progeny (O'SULLIVAN, 1980). As noted in other breeds, it was found that mares in the first third of their reproductive life, considered young, are more likely to produce champions, probably due to better reproductive tract health.

Primiparous mares accounted for $27.9 \%$ (41/147) of those that delivered winners (Figure 4). This result is different from that in Thoroughbred horses, when it is reported that horses born from the $3^{\text {rd }}$ delivery are more likely to become race winners (FINOCCHIO; 
ROSENZWEIG. 1995). It was observed that 53.7\% (79/147) of winners were born between the $2^{\text {nd }}$ and $5^{\text {th }}$ delivery, and only $18.3 \%(27 / 147)$ were born from the $6^{\text {th }}$ to $12^{\text {th }}$ delivery. Thoroughbred foals born from the $1^{\text {st }}$ to $6^{\text {th }}$ parturition had more victories in races than those born in later pregnancies, and the lowest frequency of winners was observed in foals born from the $9^{\text {th }}$ to $12^{\text {th }}$ parturition (GARCIA et al., 2011). Previous pregnancies are more harmful to fetal development than maternal age at birth, due to decreased surface of chorionic area with consequent decreased fetus nutrition (GARCIA et al., 2011). In Thoroughbred horses, a reduction in the chances of victory for foals born after the $6^{\text {th }}$ parturition is associated with the nutritional intake decrease of the fetus during pregnancy. This, in turn, is due to an increase in the degree of endometriosis, vascular alterations (SCHOON et al., 1997), placental alterations (COTTRILL et al., 1991), and glandular degeneration (ROSSDALE, 2004).

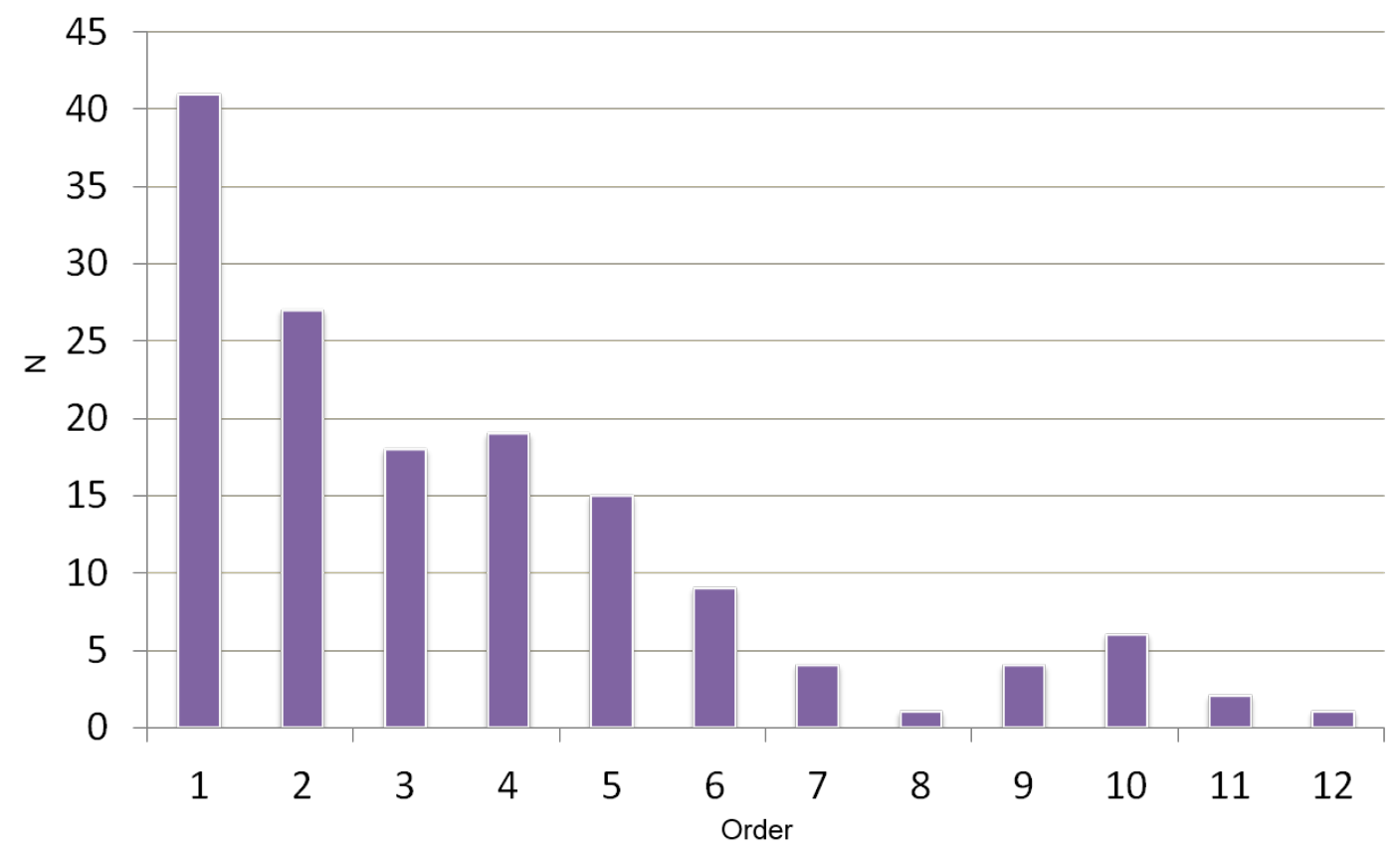

Figure 4 - Frequency distribution of mares according to order of parity of Freio de Ouro winners in the years 1982-2012. 
There is evidence of an association among parity, dam age, and performance in Thoroughbred racehorses, concluding that first foals and those from older dams tend to be less successful on the racecourse (BARRON, 1995).

The Crioulo horse has been recognized as a breed by the Association for less than one century, and the main characteristics of this breed were formed when Iberian horses were brought to South America and reproduced freely. Human interference in breeding Crioulo horses is relatively new, so some characteristics of this breed can still be attributed to natural selection.

\section{CONCLUSION}

Among the equine winners, 95.4\% have been between 4 and 11 years of age. Among the dams, 53.6\% had their first parturition before 5 years of age. In the range between 5 and 8 years old, $50.3 \%$ of the champions were born, and $81.6 \%$ of the champions were delivered between the $1^{\text {st }}$ and $5^{\text {th }}$ birth.

\section{ASPECTOS INDIVIDUAIS E MATERNOS DE CAVALOS CRIOULOS ATLETAS}

\section{RESUMO}

$\mathrm{O}$ Freio de Ouro é uma competição exclusiva para equinos da raça Crioula, sendo promovido por mais de 30 anos. A performance de equinos atletas está relacionada com características maternas. Este trabalho teve como objetivo descrever as características individuais e maternas de equinos Crioulos atletas que ganharam a competição Freio de Ouro. Um estudo retrospectivo foi realizado com dados coletados no serviço genealógico da $A B C C C$, entre os anos de 1982 a 2012. Dados analisados incluíram idade do animal ao ganhar, idade materna ao primeiro parto, idade materna ao parto do ganhador e ordem do parto. A estatística descritiva foi realizada com auxílio de programa computacional. A média de idade dos ganhadores foi de 7,1+0,17 anos, 95,4\% ganhou entre 4-11 anos e 3,2\% após 12 anos. A média de idade materna ao primeiro parto foi de $6 \pm 0,19$ anos, $53,6 \%$ das fêmeas pariram após 5 anos e consequentemente $46,4 \%$ aos 6 anos ou acima. A média de idade materna ao parto do ganhador foi de $9,2 \pm 0,37$ anos. Na faixa entre 5-8 anos, ocorreu o parto de 50,3\% dos ganhadores. Aproximadamente 5,9\% das éguas pariram ganhadores aos 4 anos ou menos, enquanto $15,6 \%$ após os 15 anos de idade. Cerca de $28 \%$ dos ganhadores nasceram de éguas primíparas, $53,7 \%$ entre o $2-5$ o e $18,3 \%$ entre o 6-12 parto. O presente estudo fornece informações retrospectivas referentes a aspectos 
individuais e maternos de equinos Crioulos ganhadores da prova Freio de Ouro nos últimos 30 anos.

Palavras-chave: Idade. Ganhadores. Nascimento. Parto. Performance.

\section{ASPECTOS INDIVIDUALES Y MATERNOS DE CABALLOS CRIOLLOS ATLETAS}

\section{RESUMEN}

$\mathrm{E}$ I Freio de Ouro es una competencia exclusiva para equinos de la raza Criolla, que ha sido promovida por más 30 años. El rendimiento de los equinos atletas se correlaciona con las características de la madre. Este trabajo tuvo como objetivo describir los aspectos individuales y maternales de los equinos Criollos atletas que han vencido en el concurso Freio de Ouro. El estudio retrospectivo se realizó con los datos recolectados en el servicio genealógico de la ABCCC, entre los años 1982 y 2012. Los datos analizados incluyeron; la edad del animal al ganar, la edad de la madre al primer parto, la edad de la madre al parir el caballo ganador y el orden de los partos. La estadística descriptiva se realizó

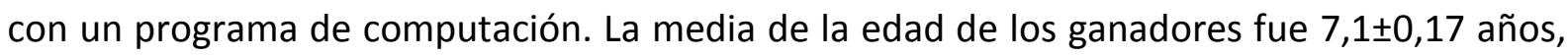
el 95,4\% de los animales ganó entre 4 y 11 años y el 3,2\% después de 12 años. La media de edad materna al primer parto fue $6 \pm 0,19$ años, el $53,6 \%$ de las hembras parieron apenas con 5 años y, consecuentemente, el $46,4 \%$ con 6 años o más. La media de la edad materna al parto en los ganadores fue 9,2 $\pm 0,37$ años. En el intervalo entre 5 y 8 años, ocurrió el parto del $50,3 \%$ de los campeones. Alrededor del 5,9\% de las madres parieron campeones a los 4 años o menos, mientras el 15,6\% apenas a los 15 años. Cerca del $28 \%$ de los campeones nacieron de yeguas primíparas, $53,7 \%$ del $2-5$ y $18,3 \%$ entre el 6-12 parto. El presente estudio proporciona informaciones retrospectivas referidas a los aspectos individuales y maternales de equinos que han ganado el Freio de Ouro en los últimos 30 años.

Palabras clave: Edad. Ganadores. Nacimiento. Parto. Performance.

\section{REFERENCES}

ABCCC - ASSOCIAÇÃO BRASILEIRA DE CRIADORES DE CAVALOS CRIOULOS. 2017. Available in: <http://www.abccc.com.br>. Access in: 10 jan. 2018.

BARRON, J. K. The effect of maternal age and parity on the racing performance of thoroughbred horses. Equine Veterinary Journal, v. 27, n. 1, p. 73-75, 1995. 
COTTRILL, C. M.; JEFFERS-LO, J.; OUSEY, J. C.; et al. The placenta as a determinant of fetal well being in normal and abnormal equine pregnancies. Journal of Reproduction and Fertility, v. 44, p. 591-601, 1991.

DAVIES-MOREL, M. C. G. Selection of the mare and the stallion for breeding. In: DAVIESMOREL, M. C. G. Equine Reproductive Physiology, Breeding and Stud Management. Wallingford: Cabi International, 2003. P. 105-130.

GARCIA, F. P. S.; ALFAYA, H.; LINS, L. A.; et al. Influence of the maternal age and number of labors in the performance of Thoroughbred horses raised in Bagé, southern Brazil. Revista Portuguesa de Ciências Veterinárias, v. 106, n. 577-580, p. 39-42, 2011.

FINOCCHIO, E. J.; ROSENZWEIG, M. Significance of birth rank, maternal age, and parity on race performance in Thoroughbreds. In: AMERICAN ASSOCIATION OF EQUINE PRACTITIONERS, 1995, Lexyngton. PROCEEDINGS, Lexyngton, 1995. P. 64-67.

LUIZ, R. C.; DE LACORTE, F. D.; BRASS, K. E. Closure time of the epiphyseal plates in the third metacarpus, radius and tibia in Criollo foals. Ciência Rural, v. 37, n. 4, p. 1052-1055, 2007.

HARRIS, P. A. Hints on nutrition for optimal growth. In: EUROPEAN EQUINE NUTRITION AND HEALTH CONGRESS, 4, 2008, Wageningen. PROCEEDINGS. Wageningen: IVIS, 2008. P. 57-80. Available in: <http://www.ivis.org/proceedings/eenhc/2008/harris.pdf?LA=1>.

MORRIS, L. H. A.; ALLEN, W. R. Reproductive efficiency of intensively managed Thoroughbred mares in Newmarket. Equine Veterinary Journal, v. 34, n. 1, p. 51, 2002.

O'SULLIVAN, D. M. An investigation into the relationship between age of dam and performance of her progeny in Thoroughbred. New Zealand Equine Veterinary Association News, p. 25-31, 1980.

ROSSDALE, P. D. The maladjusted foal: influences of intrauterine growth retardation and birth trauma. In: ANNUAL CONVENTION OF THE AMERICAN ASSOCIATION OF EQUINE PRACTITIONERS, 50, 2004, Denver, USA. PROCEEDINGS. Denver: AAEP, 2004. P. 75-126.

SCHOON, H. A.; SCHOON, D.; KLUG, E. Die endometriumbiopsie bei der Stute im klinischgynakologischen Kontext. Pferdeheilkunde, v. 13, n. 5, p. 453-464, 1997.

VULCANO, L. C.; MAMPRIM, M. J.; MUNIZ, L. M.; et al. Radiographic study of distal radial physeal closure in thoroughbred horses. Veterinary Radiology and Ultrasound, v. 38, n. 5, p. 352-354, 1997.

WILSON, J. Care of elderly horses. University of Minnesota: Extension Services, Minneapolis. 2007. Available in: <www.extension.umn.edu/horse>. Access in: 10 jan. 2018. 
WILSHER, S.; ALLEN, W. R. The effects of maternal age and parity on placental and fetal development in the mare. Equine Veterinary Journal, v. 35, n. 5, p. 476-483, 2003.

Corresponding author: Fernanda Carlini Cunha dos Santos. Departamento de Medicina Veterinária, Universidade Federal de Roraima (UFRR), Campus Cauamé, BR 174, Km 12, Monte Cristo, CEP 69300-000, Boa Vista, Roraima (RR), Brasil. carlini@portoweb.com.br 